\title{
PHARMACOLOGICAL STUDIES: ANTIBACTERIAL, ANTIOXIDANT, AND ANTI-INFLAMMATORY EFFICACY OF CASUARINA EQUISETIFOLIA ROOT EXTRACTS
}

\author{
SARANYA VTK, UMA GOWRIE S* \\ Department of Plant Biology and Plant Biotechnology, Ethiraj College for Women, Chennai - 600 008, Tamil Nadu, \\ India. Email: umasezhian@gmail.com
}

Received: 05 January 2018, Revised and Accepted: 02 May 2018

\begin{abstract}
Objective: The current study was aimed to investigate the potential phytoconstituents from Casuarina equisetifolia root extract. Qualitative, quantitative and gas chromatography-mass spectrometry (GC-MS) analysis of C. equisetifolia using various solvents of root extract was also carried out to characterize the presence of various bioactive compounds in the root. The research work was also targeted to reveal the antibacterial, antioxidant, and anti-inflammatory potential of the root extract of $C$. equisetifolia.
\end{abstract}

Methods: Root samples of $C$. equisetifolia were collected from Nimilenchery village, Pondicherry Union territory. The qualitative screening of the root extracts was carried out to check the presence of various phytoconstituents which was then followed by the quantitative analysis of phenols, flavonoids, and tannins. Further, the phytochemicals in the root extract were evaluated using GC-MS studies. In vitro antibacterial activity was performed by the agar well diffusion method using aqueous and organic solvent-based root extract against four different bacterial pathogens. In vitro antioxidant assay of different solvent extracts was elucidated using 2,2-diphenyl-1-picrylhydrazyl (DPPH) radical scavenging assay, hydrogen peroxide radical scavenging assay, and reducing power assay. Anti-inflammatory potential was also studied using protein denaturation of albumin.

Results: The qualitative phytochemical screening revealed the presence of various phytoconstituents which is of greater biological importance. Gallic acid equivalent (GAE) phenolic compound content ( $68.64 \pm 0.25 \mathrm{mg} \mathrm{GAE} / \mathrm{g}$ of extract), quercetin equivalent flavonoid content (29.09 $\pm 0.14 \mathrm{mg}$ of QUE/g of extract), tannic acid equivalent (TAE) tannin content ( $51 \pm 0.42 \mathrm{mg}$ TAE/g of extract), and terpenoid content (5.2\%) were found to be significant in the methanol root extract of $C$. equisetifolia when compared with other solvents. GC-MS analysis revealed different peaks indicating the presence of different secondary metabolites. Prominent antibacterial activity was observed in methanol extract of root, with maximum zone of inhibition exhibited against Proteus vulgaris $(23.45 \pm 0.28 \mathrm{~mm})$. The methanol root extract was most effective with half maximal inhibitory concentration (IC ${ }_{50}$ ) $52.74 \pm 0.65 \mu \mathrm{g} / \mathrm{ml}$ for DPPH and $64.94 \pm 0.24 \mu \mathrm{g} / \mathrm{ml}$ for hydrogen peroxide scavenging activity. Maximum absorbance was observed by $80 \mu \mathrm{g} / \mathrm{ml}$ $\left(\mathrm{IC}_{50} 51.79 \pm 0.26 \mu \mathrm{g} / \mathrm{ml}\right)$ of methanol root extract with respect to reducing power assay. In vitro anti-inflammatory activity had maximum inhibition of $84.6 \pm 0.26$ with $\mathrm{IC}_{50}$ value of $33.6 \pm 0.23 \mu \mathrm{g} / \mathrm{ml}$ at $80 \mu \mathrm{g} / \mathrm{ml}$.

Conclusion: From this study, it is revealed that the species of $C$. equisetifolia is a source of potential phytoconstituents exhibiting significantly various biological activities leading to the development of novel drug.

Keywords: Casuarina equisetifolia, Root, Phytochemicals, Antioxidant, Antibacterial, Anti-inflammatory, Gas chromatography-mass spectrometry.

(C) 2018 The Authors. Published by Innovare Academic Sciences Pvt Ltd. This is an open access article under the CC BY license (http://creativecommons. org/licenses/by/4. 0/) DOI: http://dx.doi.org/10.22159/ajpcr.2018.v11i8.24642

\section{INTRODUCTION}

Plants have been used as an efficient source in traditional medicine since ages. The potentiality of plants to act as therapeutic agents is based on its phytoconstituents such as phenols, flavonoids, tannins, alkaloids, proteins, amino acids, and steroids. Currently, about $75 \%$ of the population still depend on traditional medicine practices for the management of various diseases [1]. Better compatibility of plantbased medicines with the human body with very minor side effects has increased the interest to rediscover more plant-based chemical substances, which could serve as a better pharmacological active substance.

Casuarina equisetifolia belonging to the family Casuarinaceae is a rapidgrowing species (3-4 years of crop rotation) found in regions of varied climatic conditions such as coastal dunes, hot humid tropics, mountain slopes, and semi-arid regions [2]. This species has greater ability to fix atmospheric nitrogen, with the help of its symbiotic association with Frankia - An Actinomycete [3]. C. equisetifolia has been documented as a suitable species for wasteland reclamation and development due to its adaptability to a wide range of habitat, salt tolerant [4], fast growth, drought resistant, and ability to stabilized sand dunes [5]. The plantation checks soil erosion and improves environmentally degraded soil [6]. Recently, there is also a great demand for $C$. equisetifolia in paper industries as wood is used for pulping, where root and bark are the waste materials.

In addition to this, various parts of this plant have been reported to have various biological activities such as antimicrobial [7], hepatoprotective [8], antiulceric [9], and antidiabetic due to its rich phytochemical efficacy. There is a growing interest in correlating the phytochemical constituents of medicinal plants with its pharmacological activity [10]. The tree species such as C. equisetifolia is still underexplored for their medicinal properties and pharmacological investigations [11]. This species is an established agroforestry tree crop in Tamil Nadu used as an intercropping tree species due to its disease-resistant (pest and pathogen) and nitrogenfixing ability, which is mainly because of the presence of potential phytochemicals.

Thus, this study was aimed to analyze the qualitative and quantitative efficacy of phytochemicals including gas chromatography-mass spectrometry (GC-MS) analysis followed by the bioassays, namely, antibacterial, antioxidant, and anti-inflammatory potential of root extracts using various solvents. 


\section{METHODS}

\section{Collection of plant material}

The root sample of $C$. equisetifolia was collected from Nimilenchery Village, Pondicherry Union territory (Latitude: 12.10'; Longitude 79.9'), Tamil Nadu. The plant sample was taxonomically identified and authenticated as C. equisetifolia Linn., Casuarinaceae, Ref No: BSI/ SRC/5/23/2015/Tech/2012 by Botanical Survey of India, Coimbatore.

\section{Preparation of root extract}

Dried root sample of $C$. equisetifolia was cut into small pieces and surface sterilized. Extraction was carried out by adding distilled water and organic solvents (benzene, chloroform, methanol, and ethanol) in the ratio $1: 10 \mathrm{w} / \mathrm{v}$, for $48 \mathrm{~h}$, by cold percolation method. The extract was filtered, concentrated, and dried and stored at $4^{\circ} \mathrm{C}$ until further use.

\section{Qualitative phytochemical screening}

Preliminary phytochemical screening of various root extracts (aqueous, benzene, chloroform, methanol, and ethanol) was screened for the presence of phytoconstituents. The test conducted was phenols, alkaloids, flavonoids, terpenoids, carbohydrates, saponins, proteins and amino acids, phlobatannins, glycosides, and tannins using standard procedures $[12,13]$.

\section{Quantitative analysis}

\section{Estimation of total phenol content}

The content of total phenolic compound in aqueous, ethanol, and methanol extracts of $C$. equisetifolia root was determined by FolinCiocalteu reagent (FCR) [14]. Gallic acid was used as standard. To $1 \mathrm{ml}$ of each extract (different concentrations for standard gallic acid solution), $1 \mathrm{ml}$ of FCR was added in a test tube and the mixture was incubated for $5 \mathrm{~min} .10 \mathrm{ml}$ of $7 \% \mathrm{Na}_{2} \mathrm{CO}_{3}$ solution was added to the test solution and incubated in dark for $90 \mathrm{~min}$ at $23^{\circ} \mathrm{C}$. The absorbance was read at $765 \mathrm{~nm}$ against the blank. The total phenolic content in the extracts was expressed in gallic acid equivalent (GAE) using the formula:

$\mathrm{C}=(\mathrm{c} / \mathrm{V}) / \mathrm{m}$

$\mathrm{C}=$ Total phenolic content, $\mathrm{mg} / \mathrm{g}$ of plant extract in GAE

$\mathrm{c}=$ Concentration of gallic acid $(\mathrm{mg} / \mathrm{ml})$

$\mathrm{V}=$ Volume of the extract $(\mathrm{ml})$

$\mathrm{m}=$ Weight of plant extract $(\mathrm{g})$.

\section{Estimation of total flavonoid content}

The total flavonoid content was determined using aluminum chloride colorimetric method [15]. $0.5 \mathrm{ml}$ of root sample was mixed with $2 \mathrm{ml}$ of solvent and $0.3 \mathrm{ml}$ of $5 \%$ sodium nitrite solution was added. To this mixture, $0.3 \mathrm{ml}$ of $10 \% \mathrm{AlCl}_{2}, 2 \mathrm{ml}$ of $1 \mathrm{M}$ sodium hydroxide, and $2.8 \mathrm{ml}$ of distilled water were added and incubated at room temperature for $30 \mathrm{~min}$. The absorbance was read at $510 \mathrm{~nm}$ using ultraviolet (UV)-visible spectrophotometer (UV 1650 Pc, Shimadzu). Total flavonoid concentration was expressed in terms of quercetin equivalent (QE) (mg of QAE/g of extract).

\section{Estimation of tannins}

The total tannin content in aqueous, ethanol, and methanol extracts of C. equisetifolia root was estimated by Folin-Denis method [16], with modifications. To $1 \mathrm{ml}$ of plant extracts, $3 \mathrm{ml}$ of water, $0.5 \mathrm{ml}$ of Folin-Denis reagent, and $1.0 \mathrm{ml}$ of $1 \mathrm{~N}$ sodium carbonate solution were added and diluted with water. The solution was mixed thoroughly and the absorbance was read at $515 \mathrm{~nm}$. The calibration graph was plotted. Total tannin content was expressed as milligrams of tannic acid equivalent (TAE) per gram of dried sample.

\section{Estimation of total terpenoids}

Total terpenoid content was estimated [17] for ethanol, methanol, and aqueous extract of $C$. equisetifolia root. The crude extract was soaked in $20 \mathrm{ml}$ of $95 \%$ ethanol for $24 \mathrm{~h}$. The filtrate was extracted with petroleum ether $\left(60^{\circ} \mathrm{C}-80^{\circ} \mathrm{C}\right)$. The residue of the extract obtained from the petroleum ether extract was dried and weighed to estimate the total terpenoids.

$$
\text { Terpenoid content }(\%)=\frac{\text { Weight of terpenoid extract }(\mathrm{g})}{\text { Weight of sample }(\mathrm{g})} \times 100
$$

\section{GC-MS studies}

The methanol root extract was subjected to GC-MS analysis to identify the bioactive compounds. This analysis was performed in Sophisticated Instrument Facility (SIF), Vellore Institute of Technology University, Vellore, Tamil Nadu. The Clarus 680 GC was used in the analysis that employed a fused silica column, packed with Elite-5MS (5\% biphenyl $95 \%$ dimethylpolysiloxane, $30 \mathrm{~m} \times 0.25 \mathrm{~mm}$ ID $\times 250 \mu \mathrm{m} \mathrm{df}$ ). The components were separated using helium as carrier gas at a constant flow of $1 \mathrm{ml} / \mathrm{min}$. The injector temperature was set at $260^{\circ} \mathrm{C}$ during the chromatographic run. $1 \mu \mathrm{L}$ of the root extract was injected into the instrument. The oven temperature was $60^{\circ} \mathrm{C}(2 \mathrm{~min})$, followed by $300^{\circ} \mathrm{C}$ at the rate of $10^{\circ} \mathrm{C} / \mathrm{min}$ and $300^{\circ} \mathrm{C}$, where it was held for $6 \mathrm{~min}$. The mass detector conditions were transfer line temperature $240^{\circ} \mathrm{C}$, ion source temperature $240^{\circ} \mathrm{C}$, and ionization mode electron impact at 70 $\mathrm{eV}$, a scan time $0.2 \mathrm{~s}$, and scan interval of $0.1 \mathrm{~s}$ for the fragments from 40 to $600 \mathrm{Da}$. The spectrums of the components were compared with the database of spectrum of known components stored in the GC-MS NIST (2008) library.

\section{Antibacterial activity}

In vitro antibacterial activity assay of aqueous, ethanolic, and methanol root extract of $C$. equisetifolia was determined by agar well diffusion method, using Mueller-Hinton agar medium. Gentamycin $(100 \mu \mathrm{g})$ was used as positive control and solvent was used as negative control for bacterial assay. Four different concentrations $(25,50,75$, and $100 \mu \mathrm{g})$ of various root extracts were tested against Escherichia coli, Bacillus subtilis, Staphylococcus aureus, and Proteus vulgaris obtained from the Department of Microbiology, Ethiraj College for Women, Chennai. Zone of inhibition was measured after incubating the plates at $37^{\circ} \mathrm{C}$ for $24 \mathrm{~h}$. Triplicates were maintained.

\section{Antioxidant assay}

\section{2,2-Diphenyl-1-picrylhydrazyl (DPPH) radical scavenging assay}

The free radical scavenging activity of various root extract of C. equisetifolia was tested using DPPH assay method [18]. $2 \mathrm{ml}$ aliquot of DPPH solution was added to $0.5 \mathrm{ml}$ of different concentrations (20, 40,60 , and $80 \mu \mathrm{g} / \mathrm{ml}$ ) of various root extracts. The reaction mixture was incubated at room temperature for $30 \mathrm{~min}$, and then, the absorbance was determined at $517 \mathrm{~nm}$ using UV-visible spectrophotometer (UV 1650 Pc, Shimadzu). The ascorbic acid was used as a standard. Halfmaximal inhibitory concentration $\left(\mathrm{IC}_{50}\right)$ was calculated from the graph, by plotting percent inhibition against concentration. Experiments were performed in triplicates and average was calculated for each concentration.

Inhibition $\%=\left(\mathrm{OD}_{\text {blank }}-\mathrm{OD}_{\text {test }} / \mathrm{OD}_{\text {standard }}\right) \times 100$

\section{Hydrogen peroxide scavenging assay}

The ability of the extracts to scavenge hydrogen peroxide spectrometrically was determined according to the method [19]. $2 \mathrm{mM} / \mathrm{l}$ of hydrogen peroxide solution was prepared in phosphate buffer $(\mathrm{pH}=7.4)$. To different concentrations $(20,40,60$, and $80 \mu \mathrm{g} / \mathrm{ml})$ of various extracts, $0.6 \mathrm{ml}$ of hydrogen peroxide solution was added. Absorbance was measured at $230 \mathrm{~nm}$ against blank solution containing only phosphate buffer and was compared with the reference compound ascorbic acid. Experiments were performed in triplicates.

Hydrogen peroxide activity $=\left(\mathrm{Abs}_{\text {control }}-\mathrm{Abs}_{\text {sample }} / \mathrm{Abs}_{(\text {control) }}\right) \times 100$

\section{Reducing power assay}

The reducing power assay of the extracts was determined according to the standard method [20]. Different concentrations $(20,40,60$, and $80 \mu \mathrm{g} / \mathrm{ml}$ ) of various root extracts of $C$. equisetifolia were mixed with $2.5 \mathrm{ml}$ of $0.2 \mathrm{M}$ phosphate buffer $(\mathrm{pH}=6.6)$ and $2.5 \mathrm{ml}$ of $1 \%$ 
potassium ferricyanide. The reaction mixture was incubated at $50^{\circ} \mathrm{C}$ for $20 \mathrm{~min}$. After incubation, $2.5 \mathrm{ml}$ of $10 \%$ trichloroacetic acid was added to the reaction mixture and centrifuged at $3000 \mathrm{rpm}$ for $10 \mathrm{~min}$. $2.5 \mathrm{ml}$ of the supernatant was collected and mixed with $0.5 \mathrm{ml}$ of $0.1 \% \mathrm{FeCl}_{3}$. The absorbance was measured at $700 \mathrm{~nm}$ using UV-visible spectrophotometer (UV 1650 Pc, Shimadzu) and was compared with the reference compound ascorbic acid. Experiments were performed in triplicates.

\section{In vitro anti-inflammatory activity}

The anti-inflammatory activity of $C$. equisetifolia root extract using different solvents was studied by standard method of inhibition of albumin denaturation [21]. The reaction mixture consists of different concentrations $(20,40,60$, and $80 \mu \mathrm{g})$ of different solvent extracts and $1 \%$ of aqueous bovine albumin fraction, and $\mathrm{pH}$ was adjusted using $1 \mathrm{~N}$ $\mathrm{HCl}$. The reaction mixture was incubated at $37^{\circ} \mathrm{C}$ for $10 \mathrm{~min}$ and then heated at $51^{\circ} \mathrm{C}$ for $20 \mathrm{~min}$. The turbidity was measured at $660 \mathrm{~nm}$ using UV-visible spectrophotometer (UV 1650 Pc, Shimadzu) after cooling and was compared with the reference compound diclofenac sodium. Experiments were performed in triplicates.

Percent inhibition of protein denaturation was calculated using the formula:

Percent inhibition $=\left(\mathrm{Abs}_{\text {control }}-\mathrm{Abs}_{\text {sample }} / \mathrm{Abs}_{\text {(control) }}\right) \times 100$

\section{Statistical analysis}

Results are expressed as mean \pm standard error. The experimental data were analyzed using analysis of variance (ANOVA).

\section{RESULTS AND DISCUSSION}

\section{Phytochemical screening}

Qualitative analysis of phytochemicals revealed the presence of phenols, flavonoids, terpenoids, carbohydrates, saponins, and tannins in aqueous, ethanol, and methanol root extract of $C$. equisetifolia (Table 1). Benzene and chloroform extract showed the presence of phenols, alkaloids, glycosides, and tannins. The presence of phlobatannins was observed only in ethanol and methanol root extract. The Observations from this study can be correlated with the polarity of extracted compounds in various solvents. Studies conducted by Gopichand et al., 2015 [22], showed the presence of alkaloids, flavonoids, phenols, terpenoids, and tannins in C. equisetifolia root extract.

Phytochemicals are naturally occurring substances produced by plants during primary and secondary metabolism. These phytochemicals play a key role in biological activities of the plant, plant growth, and defense against competitors, pathogens, or predators [23]. These plant secondary metabolites have the efficacy to stimulate the human immune system, act as an antioxidant [24], reduce inflammation and oxidative damages caused by the cell apoptosis, regulate intercellular signaling of hormones and genes, and slow down the growth rate of cancer cell [25] and also as potential antibacterial agents [26].

Thus, the phytochemical analysis revealed the presence of prominent phytochemicals, which could develop a symbiotic chemistry with human metabolism and help to treat various diseases. Since maximum solubility of phytochemicals was observed in aqueous, ethanol, and methanol root extracts in qualitative phytochemical analysis, further quantification and in vitro studies were carried out only with these three root extracts.

\section{Quantitative phytochemical analysis}

The total phenolic content was calculated using standard curve of gallic acid ( $\left.\mathrm{y}=0.175 \mathrm{x}-0.118, \mathrm{R}^{2}=0.995\right)$ and expressed in GAE/g of extract. Methanol extract of root demonstrated higher total phenolic content ( $68.64 \pm 0.63 \mathrm{mg} \mathrm{GAE} / \mathrm{g}$ of extract) which was followed by ethanol and aqueous extracts with $64.60 \pm 0.63$ and $32.96 \pm 0.77 \mathrm{mg} \mathrm{GAE} / \mathrm{g}$ of extract, respectively (Fig. 1).

The total flavonoid content was calculated using standard curve of quercetin ( $\left.\mathrm{y}=0.013 \mathrm{x}-0.161 \mathrm{R}^{2}=0.990\right)$ and expressed in $\mathrm{QE} / \mathrm{g}$ of extract. The total flavonoid content was high in methanol root extract $(29.09 \pm 0.54 \mathrm{mg}$ of $\mathrm{QE} / \mathrm{g}$ of extract) followed by ethanol and aqueous extracts with $26.23 \pm 0.38$ and $23.88 \pm 0.67 \mathrm{mg} \mathrm{QE} / \mathrm{g}$ of extract, respectively (Fig. 1).

The total tannin content was calculated using standard curve of tannic acid $\left(y=0.003 x-0.007 R^{2}=0.994\right)$ and expressed in TAE/g of extract. Among the various solvents used, methanol extract revealed the highest tannin content of $51.6 \pm 0.82 \mathrm{mg}$ TAE$/ \mathrm{g}$ of extract followed by ethanol and aqueous extracts with $42.17 \pm 0.50$ and $16.68 \pm 0.61 \mathrm{mg} \mathrm{TAE} / \mathrm{g}$ of extract, respectively (Fig. 1).

The methanol root extracts showed maximum terpenoid content $(5.20 \pm 0.52 \%)$ followed by ethanol extract $(3.56 \pm 0.63 \%)$ and aqueous extract $(2.58 \pm 0.77 \%)$.

Among the solvents used, there was a significant variation $(\mathrm{p}<0.001)$ in the phytochemicals quantified in which methanol extract was proved to be an effective solvent for biological assays.

Increase in the level of phenolic compounds enhances the quality of plants, serves as a tool for plant growth and reproduction, and is produced as a response to environmental factors such as light, pollution, and irradiation [27]. Epidemiological studies have proved the positive effect of phenols on human health since they decrease the coronary heart disease, control the platelet aggregations [28], have both in vitro and in vivo $[29,30]$ antioxidant capacities, and also possess anticarcinogenic protection. Various biological activities of phenolic compounds include bile secretion, lowering of blood cholesterol and lipid levels, anti-inflammatory activity, and antibacterial activity against wide range of pathogens when taken in regular diet [31].

Flavonoid is a polyphenolic secondary metabolite [32]. Flavonoids give rich taste to plants that help in pollination and as a repellent to pest [33] and are also responsible for pigmentation of various parts of the plant and involved in nodule formation [34]. It is well known for their potential antioxidant property, which prevents the cell against the damage caused by free radicals by acting as scavengers of free radicals such as reactive oxygen species (ROS) and chelating metals [35].

Table 1: Phytochemical analysis of different extracts of root

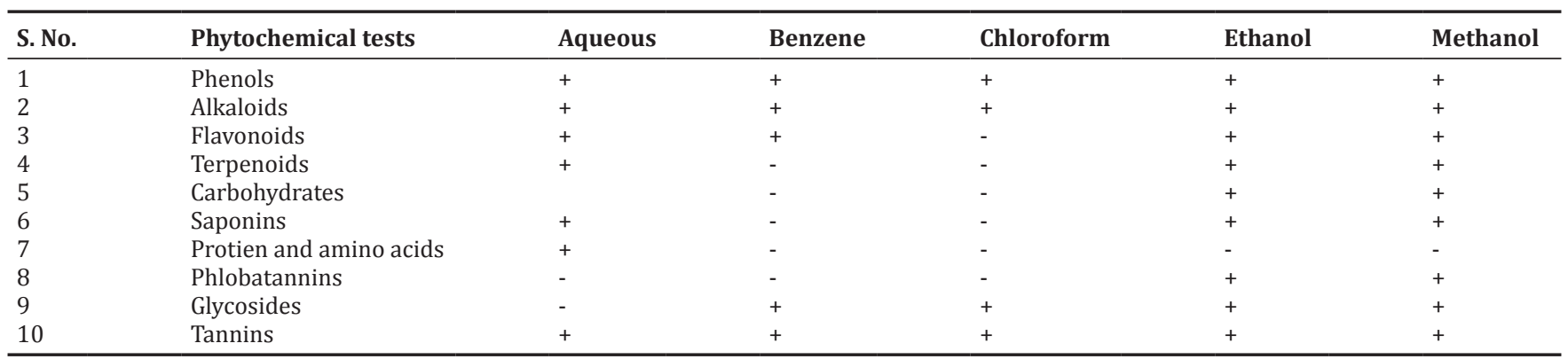


Flavonoids have been found to modulate the inflammation mediators such as Interleukin 6, which helps it to serve as an efficient antiinflammatory agent [36].

Tannin is a polyphenolic complex, which serves as defensive secondary metabolite in plants, by protecting it from insects and herbivores, because of its bitter taste. The structure of tannic acid possesses hydrophobic core and hydrophilic shell which could be responsible for the antioxidant potential [37]. Antioxidant property of tannic acid is also attributed due to its ability to suppress the hydroxyl radical formation $[38,39]$.

Terpenoids play a vital role by exerting metabolic control, mediating inter- and intraspecies interaction such as pollination and defense mechanism [40]. Terpenoids with provitamin A act as an important source for vision; it also influence the human immune system. Gapjunctional communication that influence the inflammatory mediators and prevents inflammation [41]. The potential of terpenoids to quench singlet oxygen, hydrogen transfer, and electron transfer proves it as a potent antioxidant agent [42]

\section{GC-MS study}

GC-MS chromatogram analysis of the root methanol extract of $C$. equisetifolia showed eight peaks indicating the presence of eight phytochemical constituents. The mass spectra were compared with the NIST library, and the eight phytocompounds were characterized and identified. The various phytochemicals characterized contribute to the medicinal activities of the plant. The eight compounds were identified as, trihydroxybenzoic acid, 2,4,10-trioxatricyclo, 1,3-dichloropentane, 2-butanone-4-hydroxy, D-galactonic acid- gamma lactone, butanoic acid - 3-cyano-3-hydroxy ethyl ester, 1-nitro 2-acetamido-1,2 dideoxy-D-manitol, oxalic acid isohexyl pentyl ester (Fig. 2). Among the phytoconstituents, trihydroxybenzoic acid was reported to have antimicrobial, antioxidant, anti-inflammatory potential [43]. Oxalic acid and isohexyl pentyl ester are used as plasticizer [44]. Trihydroxybenzoic acid is a phenolic compound involved in the defense against certain pathogens causing human and animal diseases [45]. Their activity is a function of the lipophilic properties of the constituent, functional groups, and their solubility [46].

The presence of various bioactive compounds in $C$. equisetifolia justifies the use of root extracts for various ailments by traditional practitioners.

\section{Antibacterial activity}

Organic solvent root extracts exhibited more consistent antibacterial activity than aqueous root extract. Antibacterial activity increased with the increase in the concentration of the extract. The maximum zone of inhibition of $23.45 \pm 0.28 \mathrm{~mm}$ was exhibited by methanol root extract of $C$. equisetifolia against $P$. vulgaris at $100 \mu$ concentration. The ethanolic and aqueous root extract showed maximum zone of inhibition against $P$. vulgaris $(21.45 \pm 0.74 \mathrm{~mm})$ and $B$. subtilis $(16.55 \pm 0.48 \mathrm{~mm})$, respectively, at $100 \mu \mathrm{g}$ concentration (Fig. 3), whereas the study conducted by [47] in the methanol root extract of related Casuarina species (Casuarina junghuhniana) showed maximum zone of inhibition against $B$. subtilis $(19 \pm 0.2 \mathrm{~mm})$.

This activity could be due to the ability of the secondary metabolites to form a complex with extracellular proteins and with the cell wall of bacteria [48]. The inhibitory effect of methanol root extract, on the growth of bacteria, might be due to higher solubility of these potential secondary metabolites, which indicates the presence of broad spectrum of antibiotic compounds [43].

The organic solvent of the plant extract had more antibacterial potential than the aqueous extract. This observation can be correlated with the polarity of the solvent used for extraction, intrinsic bioactivity, and ability to diffuse in media used in assay [49].

The presence of alkaloids, phenols, carbohydrates, flavonoids, and tannins in the root extract may be responsible for the antibacterial efficacy of the root extracts [50].Phenolic compounds possess a C3 side chain which has a lower level of oxidation and containing no oxygen are often cited as the reason for the antimicrobial potential [51]. Terpenoids and flavonoids act as an effective antimicrobial agent due to its ability to disrupt the membrane of lipophilic compounds present in the microbial cell [52]. The antibacterial ability of the extract may also be due to the ability of tannin to hydrolyze the ester linkage between gallic acid and polyols [53]. Thus, tannin-rich plant parts have natural defense against microbial infection [54].

\section{Antioxidant activity}

$D P P H$ radical scavenging activity

DPPH radical scavenging assay estimates the ability of the extract to

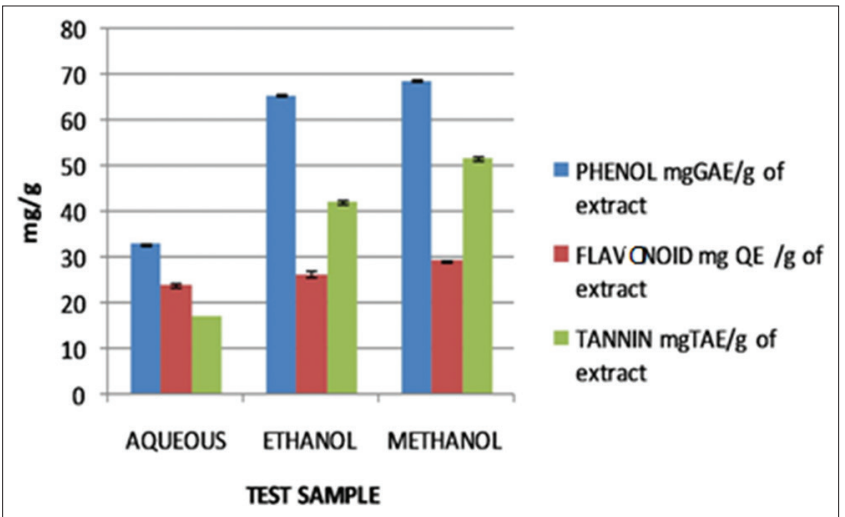

Fig. 1: Quantitative analysis (total phenol, total flavonoid, and total tannin)

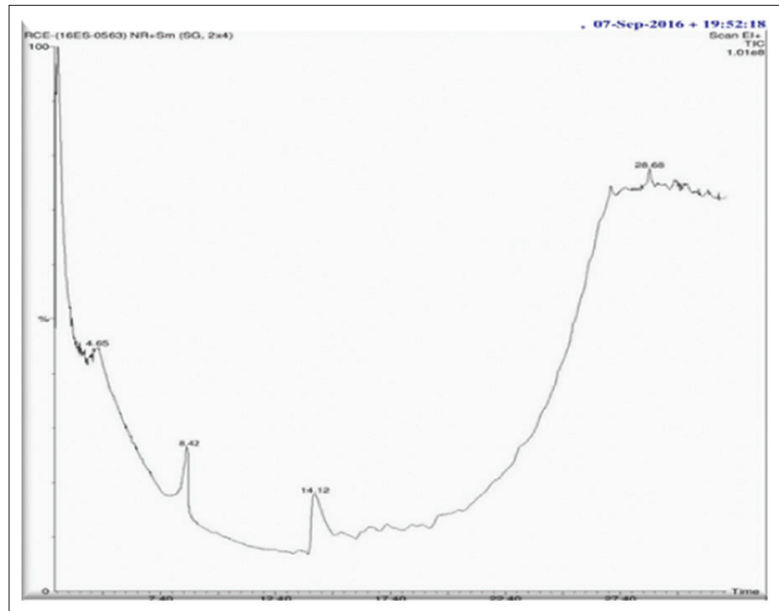

Fig. 2: Gas chromatography-mass spectrometry chromatogram of methanol extract of Casuarina equisetifolia

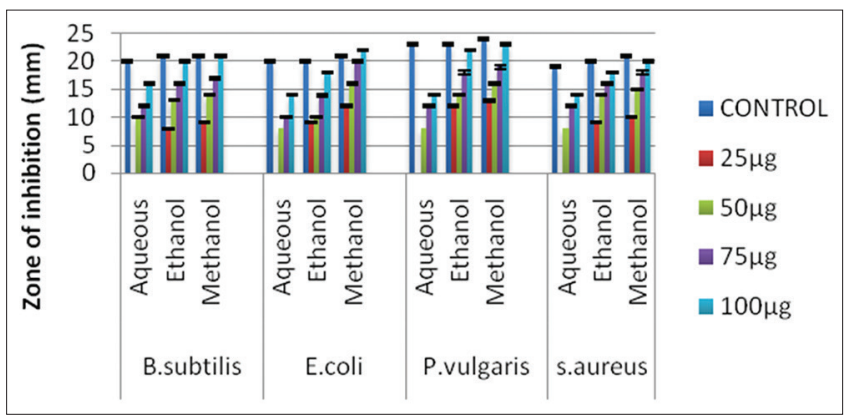

Fig. 3: Antibacterial activity of Casuarina equisetifolia root extracts against different bacterial pathogens 
donate hydrogen or to scavenge the free radical. The results revealed that the methanol root extract of $C$. equisetifolia exhibited the highest scavenging activity with $\mathrm{IC}_{50}$ value followed by ethanolic and aqueous root extracts (Fig. 4). The methanol extract showed percent maximum inhibition at $80 \mu \mathrm{g}$ concentration $(86.82 \pm 0.65)$ followed by ethanol extract $(85.46 \pm 0.55)$ and aqueous extracts $(82.73 \pm 0.48)$, with $\mathrm{IC}_{50}$ value of $52.74 \pm 0.65,54.86 \pm 0.86$, and $57.83 \pm 0.72 \mu \mathrm{g} / \mathrm{ml}$, respectively. The DPPH activity of standard ascorbic acid showed maximum percent inhibition of $(96.34 \pm 0.82)$ at $80 \mu \mathrm{g}$ concentration with $\mathrm{IC}_{50}$ value of $39.22 \pm 0.73 \mu \mathrm{g} / \mathrm{ml}$. Lower $\mathrm{IC}_{50}$ value indicates greater antioxidant activity. Methanol extract of $C$. equisetifolia root showed significant $(p<0.001)$ scavenging activity which may be attributed to the presence of greater amount of phenols and tannins.

\section{Hydrogen peroxide scavenging assay}

In the presence of metal ions and superoxide anion, hydrogen peroxide gets converted into hydroxyl radical and also produces singlet oxygen. Thus, it acts as a toxicant to the cell. Hydrogen peroxide can also degrade heme protein and release Fe ions, thus supporting the scavenging activity. The methanol extract showed percent maximum inhibition at $80 \mu \mathrm{g}$ concentration $(58.15 \pm 0.25)$ followed by ethanol extract $(53.93 \pm 0.38)$ and aqueous extracts $(50.47 \pm 0.56)$, with $\mathrm{IC}_{50}$ value of $64.94 \pm 0.24,70.73 \pm 0.36$, and $76.51 \pm 0.08 \mu \mathrm{g} / \mathrm{ml}$, respectively. With regard to hydrogen peroxide scavenging activity, IC $_{50}$ value indicates methanol root extract as an efficient scavenger. The $\mathrm{IC}_{50}$ value of standard ascorbic acid was $44.56 \pm 0.15 \mu \mathrm{g} / \mathrm{ml}$ with percent inhibition of $89.2 \pm 0.76$ (Fig. 5).

\section{Reducing power assay}

The reducing power of the extract is marked by the reduction of $\mathrm{Fe}^{3+}$ complex (ferric cyanide) to ferrous that serves as an efficient indicator for potential antioxidant activity which is due to the presence of reductones. The reducing power of $C$. equisetifolia root extract expressed as the function of their concentration. There was an increase in reducing power with the increase in the concentration of aqueous, ethanol, and methanol root extract of $C$. equisetifolia (Fig. 6). Higher absorbance of the reaction mixture indicates more reducing potential. The methanol extract showed percent maximum inhibition at $80 \mu \mathrm{g}$

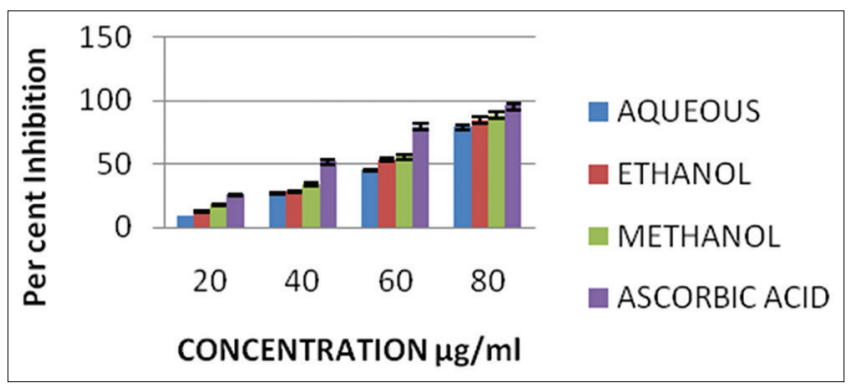

Fig. 4: 2,2-diphenyl-1-picrylhydrazyl-free radical scavenging activity of Casuarina equisetifolia root extracts

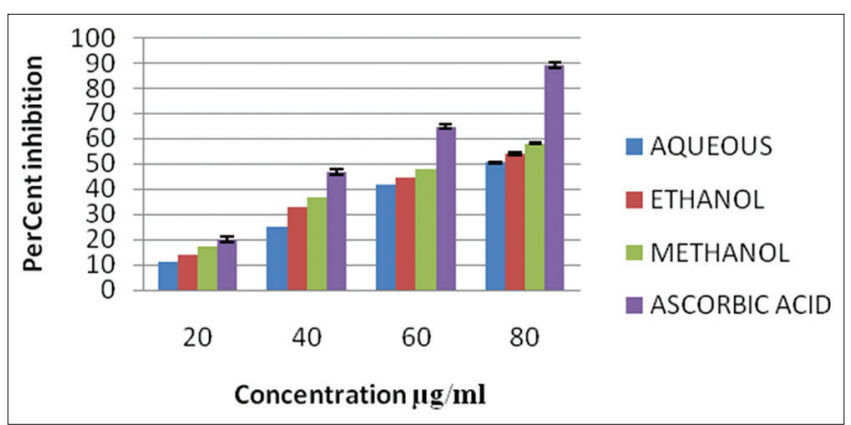

Fig. 5: Hydrogen peroxide scavenging activity of Casuarina equisetifolia root extracts concentration (77.46 \pm 0.63$)$ followed by ethanol extract $(72.30 \pm 0.37)$ and aqueous extract $(65.25 \pm 0.65)$, respectively, with $\mathrm{IC}_{50}$ value of $51.79 \pm 0.26,55.13 \pm 0.73$, and $61.82 \pm 0.41 \mu \mathrm{g} / \mathrm{ml}$, respectively. The reducing power of standard ascorbic acid showed maximum percent inhibition of $82.16 \pm 0.15\left(\mathrm{IC}_{50}\right.$ value of $\left.47.27 \pm 0.31 \mu \mathrm{g} / \mathrm{ml}\right)$ at $80 \mu \mathrm{g}$ concentration.

A substance when present at lower concentration prevents oxidation of cellular substances like proteins, lipids, carbohydrates and DNA which contributes to the antioxidant property [55]. Plant polyphenols are diverse group of compounds, including tannins and flavonoids occurring naturally in plant products that acts as an effective antioxidant agent by quenching singlet and triplet oxygen, decomposing peroxidases and neutralizing free radicals [56].

The antioxidant property of the phenolic compounds may be related to its ability to inhibit lipoxygenase, chelate metal ions, and scavenge free radicals and thus controls ROS $\left(\mathrm{O}_{2}, \mathrm{H}_{2} \mathrm{O}_{2}, \mathrm{NO}\right)$ [57]. The presence of tannin which has the ability to suppress hydroxyl radical formation [58] might also be responsible for the antioxidant action. Flavonoids effectively scavenges most of the oxidizing molecules, including singlet oxygen, and various free radicals [59] (Bravo., 1998)Similarly, terpenoids act as regulators of metabolism and plays a protective role as antioxidant.

Preliminary phytochemical analysis of root extract of various solvents confirmed the presence of phenol and phenolic compounds attributing to the potential antioxidant activity, of which methanol root extract of $C$. equisetifolia possesses efficient antioxidant activity. This result is in accordance with the study conducted in C. equisetifolia [24], where the root extracts exhibited maximum antioxidant-free radical scavenging activity. The bioactive compound present in the extract may be separated and purified which may also be employed as a drug in treating various human diseases in which free radicals are involved, such as cancer, cardiovascular diseases, and aging.

\section{In vitro anti-inflammatory activity}

In anti-inflammatory assay of C. equisetifolia root extracts, the results revealed inhibition of thermally induced protein (albumin)

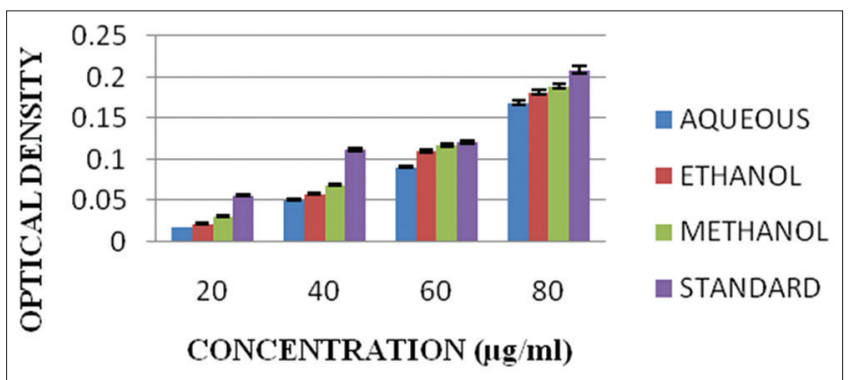

Fig. 6: Reducing power activity of Casuarina equisetifolia root extracts

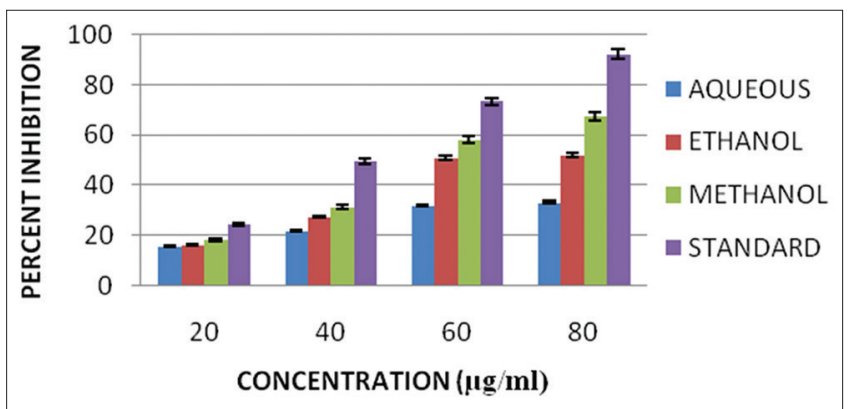

Fig. 7: Anti-inflammatory activity of Casuarina equisetifolia root extracts 
denaturation in dose-dependent manner (Fig. 7). The methanol extract showed maximum percent inhibition of $84.6 \pm 0.23$ when compared to ethanol extract of $76.3 \pm 0.31$ and aqueous extract of $50.42 \pm 0.14$ with $\mathrm{IC}_{50}$ value of $33.6 \pm 0.52,52 \pm 0.47$, and $65 \pm 0.31 \mu \mathrm{g} / \mathrm{ml}$, respectively. The anti-inflammatory activity of standard diclofenac sodium showed maximum percent inhibition of $92.35 \pm 0.7$ at $80 \mu \mathrm{g}$ concentration with $\mathrm{IC}_{50}$ value of $40.80 \pm 0.47 \mu \mathrm{g} / \mathrm{ml}$.

Inflammation is a biological defense mechanism, executed by the production of pro-inflammatory mediators. Overproduction of these mediators leads to chronic degenerative diseases such as, asthma, Alzheimer's disease, arthritis, and cancer [60]. Currently, inflammation is treated using nonsteroidal anti-inflammatory drugs - salicylate derivatives that produce many side effects such as renal failure, hypersensitive reactions, and gastrointestinal disorders [61]. Thus, secondary metabolites such as polyphenolic compounds obtained from plants could serve as an alternative in inflammation treatment, with minimal or null side effects. Anti-inflammatory activity of phenolic compounds may be due to its ability to inhibit the synthesis of pro-inflammatory mediators and ability to modify the eicosanoid synthesis and inhibit the activated immune cells through its inhibitory effects on nuclear factor- $\kappa \mathrm{B}$ responsible for inflammation [62]. The tannins were found to antagonize the permeability-increasing effects of certain pro-inflammatory mediators and inhibit the migration of leukocytes (mainly lymphocytes - B-cells) to the inflammatory site, thus preventing inflammation [63]. The astringent property of tannins acts on the cell membrane, interfering in the inflammation of cell, and prevents inflammation [64]. Tannins also help to heal wound due to its antimicrobial property [65].

\section{CONCLUSION}

The above study clearly indicates that the polarity of solvents plays a vital role in extraction of phytoconstituents. The potential of solvent extract of $C$. equisetifolia root may be due to the presence of diverse phytoconstituents such as phenols, flavonoids, tannins, and terpenoids in crude extracts. In conclusion, this study has proved that the methanol root extract of $C$. equisetifolia in association with compounds of GCMS analysis maybe an efficient therapeutic agent by being a potent antibacterial, antioxidant, and anti-inflammatory agent. Investigation is also being made to isolate, purify, and characterize the bioactive compound that is pharmacologically involved in these bioactivities. The isolated compound may serve as a powerful prototypes of antibacterial, antioxidant, and anti-inflammatory drugs with less or no side effects.

\section{ACKNOWLEDGMENT}

The authors thank Mrs. V. Manimozhi, Associate Professor and Head, the faculty members and supporting staff of the Department of Plant Biology and Plant Biotechnology, Mrs. Prema Sampathkumar, Former Head of the Department, and Dr. Mrs. A. Nirmala, Principal, Ethiraj College for Women (Autonomous) Chennai - 600 008, for their valuable support and encouragement throughout the entire period of research. We would also like to express our thanks for the facilities extended by the Central Instrumentation Centre of Ethiraj College for Women.

\section{AUTHOR'S CONTRIBUTION}

Dr. S. Uma Gowrie: Design of the research and data analysis. Saranya: Execution of the research design and drafting of the article. All the authors contributed equally.

\section{CONFLICTS OF INTEREST}

The authors declare that they have no conflict of interest in the publication.

\section{REFERENCES}

1. Olajuyigbe OO, Afolayan AJ. Pharmacological assessment of the medicinal potential of Acacia mearnsii De Wild. Antimicrobial and toxicity activities. Int J Mol Sci 2012;13:4255-67.

2. Nicodemus A, Kannan K, Sagariya YC, Vipin P, Durai A, Singh BG. Clonal evaluation of Casuarina junghuhniana for growth and stem form in south India. In: Nicodemus A, Pinyopusarerk K, Zhong CL, Franche C, editors. Casuarina improvement for securing rural livelihoods. Proceedings of $5^{\text {th }}$ International Casuarina Workshop; 2016. p. 99-103.

3. Baker DD, O'Keefe. A modified sucrose fractionation procedure for the isolation of actinorhizal root nodules and soil samples. Plant Soil 1984;78:23-8

4. Yadav JS. Physcio-chemical characteristic of some soil types of Indian Forests. Indian For 1968;94:85-98.

5. Subramaniyam KN, Bedellk PE, George MG, Mandal AK, Pillai SR, Singh PG. Casuarina Trees of Multiple Ability. Dehra Dum: ICFRE; 1992. p. 29-115.

6. Kondas S. Casuarina equisetifolia multipurpose cash crop in India. Midgley SJ, Turnbull JW, Johnson RD, editors. In: Casuarina Ecology Management and Utilization. Melbourne Australia: CSIRO; 1983. p. 66-76.

7. Parekh J, Jadeja D, Chanda S. Efficacy of aqueous and methanol extracts of some medicinal plants for potential antibacterial activity. Turk J Biol 1971;29:203-10.

8. Ahsan MR, Islam KM, Bulbul IJ. Hepatoprotective activity of methanol extract of some medicinal plants against carbon tetrachloride-induced hepatotoxicity in rats. Eur J Sci Res 2009;37:302-10.

9. Shalini S, Kumar AS. Study on phytochemical profile and antiulcerogenic effect of Casuarina equisetifolia L. Asian J Pharm Sci Technol 2011;1:12-7.

10. Krishnaraju AV, Rao TV, Sundararaju D. Assessment of bioactivity of Indian medicinal plants using Brine shrimp (Artemia salina) lethality assay. Int J Appl Sci Eng 2005;2:125-34.

11. De B, Debbarma T, Sen S, Chakraborty R. Tribal life in the environment and biodiversity of Tripura, India. Curr World Environ 2010;5:59-66.

12. Harborne AJ. Phytochemical Methods a Guide to Modern Techniques of Plant Analysis. Vol. 3. Netherlands: Springer; 1998. p. 1-8.

13. Raaman N. Phytochmeical Techniques. Vol. 5. New Delhi: New India Publishing Agency; 2006. p. 19-25.

14. Singleton VL, Orthofer R, Lamuela-Raventos RM. Analysis of totalphenols and other oxidation substrates and antioxidants by means of Folin-Ciocalteu reagent. Methods Enzymol 1999;299:152-78.

15. Chang C, Yang M, Wen H, Chern J. Estimation of total flavonoid content in propolis by two complementary colorimetric methods. J Food Drug Anal 2002;10:178-82.

16. Sadasivam S, Manickam A. Biochemical Methods for Agricultural Sciences. New Delhi: Wiley Eatern Limited.; 1992. p. 6-7, 188-9.

17. Tejavathi DH, Jayashree DR. Phytochemical screening of selected medicinal herbs inoculated with arbuscular mycorrhizal fungi. Int J Biol Pharm Allied Sci 2013;2:2090-106.

18. Blios MS. Antioxidant determinations by the use of a stable free radical. Nature 1958;26:1199-200

19. Ruch RJ, Cheng SJ, Klaunig JE. Prevention of cytotoxicity and inhibition of intercellular communication by antioxidant catechins isolated from Chinese green tea. Carcinogenesis 1989;10:1003-8.

20. Oyaizu M. Studies on products of browning reaction: Antioxidative activities of products of browning reaction prepared from glucosamine. Jpn J Nutr 1986;44:307-14.

21. Mizushima Y, Kobayashi M. Interaction of anti-inflammatory drugs with serum preoteins, especially with some biologically active proteins. J Pharm Pharmacol 1968;20:169-217.

22. Ch VG, Anjani A, Himaja A, Shilpa UU, Kumar AR, Eswaraiah MC. Phytochemical evaluation of Lantana camara, Casuarina equisetifolia, Michella nilagirica. Indian J Res Pharm Biotechnol 2015;3:461-63.

23. Lewinsohn E, Schalechet F, Wilkinson J, Matsui K, Tadmor Y, Nam K, et al. Enhanced levels of the aroma and flavor compound S-linalool by metabolic engineering of the terpenoid pathway in tomato fruits. Plant Physiol 2001;127:1256-65.

24. Bristy NJ, Islam MF, Anisuzzaman SF, Alam MN. Antioxidant activity of the water extracts of leaves, root barks, barks of Casuarina littorea. Aust J Basic Appl Sci 2014;8:419-26.

25. Hanhineva K, Törrönen R, Bondia-Pons I, Pekkinen J, Kolehmainen M, Mykkänen $\mathrm{H}$, et al. Impact of dietary polyphenols on carbohydrate metabolism. Int J Mol Sci 2010;11:1365-402.

26. Rojas R, Bustamante B, Bauer J, Fernandex I, Alban J, Lock O. Antimicrobial activity of selected Peruvian medicinal plants. J Ethnopharmacol 2003;88:199-204.

27. Balandrin MF, Kjocke AJ, Wurtele E. Natural plant chemicals: Sources of industrial and mechanical materials. Science 1985;228:1154-60. 
28. Burns J, Gardner PT, O’Neil J, Crawford S, Morecroft I, McPhail DB, et al. Relationship among antioxidant activity, vasodilation capacity, and phenolic content of red wines. J Agric Food Chem 2000;48:220-30.

29. Fernández-Pachón MS, Vollaño D, García-Parrilla MC, Troncoso AM. Antioxidant activity of wines and relation with their polyphenolic composition. Anal Chim Acta 2004;513:113-8.

30. Wang J, Ho L, Zhao Z, Seror I, Humala N, Dickstein DL, et al. Moderate consumption of cabernet sauvignon attenuates abeta neuropathology in a mouse model of Alzheimer's disease. FASEB J 2006;20:2313-20.

31. Leung AY. Encyclopedia of Common Natural Ingredients used in Food, Drugs and Cosmetics. New York: John Wiley \& Sons; 1980. p. 231.

32. Valentine IK, Maria VK, Bruno B. Phenolic cycle in plants and environment. J Mol Cell Biol 2003;2:13-8.

33. Harborne JB. Functions of Flavonoids in Plants. In: Goodwin TW, editor. Chemistry and Biochemistry of Plant Pigments. New York: Academic Press; 1976. p. 736-78.

34. Mol J, Grotewold E, Koes R. How genes paint flowers and seeds. Trends Plant Sci 1998;3:212-7.

35. Korkina LG, Afanas'ev IB. In: Sies H, editor. Antioxidants in Disease Mechanisms and Therapy. San Diego: Academic Press; 1997.p. 151-63.

36. Stote KS, Clevidence BA, Novotny JA, Henderson T, Radecki SV, Baer DJ, et al. Effect of cocoa and green tea on biomarkers of glucose regulation, oxidative stress, inflammation and hemostasis in obese adults at risk for insulin resistance. Eur J Clin Nutr 2012;66:1153-9.

37. Isenburg JC, Karamchandani NV, Simionescu DT, Vyavahare NR. Structural requirements for stabilization of vascular elastin by polyphenolic tannins. Biomaterials 2006;27:3645

38. Andrade RG, Dalvi LT, Silva JM, Lopes GK, Alonso A, HermesLima M. The antioxidant effect of tannic acid on the in vitro coppermediated formation of free radicals. Arch Biochem Biophys 2005;437:1.

39. Vance RE, Teel RW. Effect of tannic acid on rat liver S9 mediated mutagenesis, metabolism and DNA binding of benzo[a]-pyrene. Cancer Lett 1898;47:37.

40. Williams R, Spencer J, Rice-Evans C. Flavonoids: Antioxidants or signalling molecules, freeradic. Biol Med 2004;36:838-49.

41. Letourneao DK. Conceptual framework of three-trophic level interactions. In: Barbosa P, Letoumeau DK, editors. Novel Aspects of Insect-Plant Interactions. New York: John Wiley \& Sons; 1988. p. 1-9.

42. Grassmann J. Terpenoids as plant antioxidants. Vitam Horm 2005;72:505-35

43. Kuete V, Nguemeving JR, Beng VP, Azebaze AG, Etoa FX, Meyer M, et al. Antimicrobial activity of the methanol extracts and compounds from Vismia laurentii De Wild (Guttiferae). J Ethnopharmacol 2007;109:372-79.

44. Silverstein RM, Webster FX. Spectroscopic Identification of Organic Compounds. $6^{\text {th }}$ ed. Ch. 4. New York, USA: John Wiley and Sons; 1997.

45. Yim TK, Wu WK, Mak DH, Ko KM. Myocardial protective effect of an anthraquinone containing extract of Polygonum multiflorum. Planta Med 1998;64:607-11.

46. Hostettman K. Strategy of the biological and chemical evaluation of plant extracts. IUPAC 1998;70:21-2.

47. Chathurdevi G, Umagowrie S. Potent bioactive metabolites of
Casuarina Junghuhniana miq. Roots a therapeutic approach. Int J Pharm Sci 2017;9:158-65.

48. Marjorie C. Plant products as antimicrobial agents. Clin Microbiol Rev 1999; 12:564-82

49. Ikigai H, Nakae T, Hara Y, Shimamura T. Bactericidal catechins damage the lipid bilayer. Biochim Biophys Acta 1993;1147:132-6.

50. Jigna PA, Darshana JA, Sumitra CH. Efficacy of aqueous and methanol extracts of some medicinal plants for potential antibacterial activity. Turk J Biol 2005;29:203-10.

51. Duke JA. Handbook of Medicinal Herbs. Boca Raton, Fla: CRC Press, Inc.; 1985.

52. Georges M, Pandelai KM. Investigations on plant antibiotics. IV. Further search for antibiotic substances in Indian medicinal plants. Indian J Med Res 1949;37:169-81.

53. Chung KT, Stevens SE Jr., Lin WF, Wei CI. Growth inhibition of selected food-borne bacteria by tannic acid, propyl gallate and related compounds. Lett Appl Microbiol 1993;17:29-32.

54. Doughari JH. Antimicrobial Activity of Tamarindus indica Linn. Trop J Pharm Res 2006;5:597-603.

55. Halliwell B, Aeschbach R, Löliger J, Aruoma OI. The characterization of antioxidants. Food Chem Toxicol 1995;33:601-17

56. Osawa T. Novel natural antioxidants for utilization in food and biological systems. In: Uritani I, Garcia VV, Mendoza EM, editors. Postharvest Biochemistry of Plant Food-Materials in the Tropics. Japan: Japan Scientific Societies Press; 1994. p. 241-51.

57. Mishra SL, Sinhamahapatra PK, Nayak A, Das R, Sannigrahi S. In vitro antioxidant potential of differentparts of Oxoxylum indicum: A comparative study. Indian J Pharm Sci 2010;72:267-9.

58. Dudonne S, Vitrac X, Coutiere P, Woillez M, Merillon JM. Comparative study of antioxidant properties and total phenolic content of 30 plant extracts of industrial interest using DPPH, ABTS, FRAP, SOD, and ORAC assays. J Agric Food Chem 2009;57:1768-74

59. Bravo L. Polyphenols: Chemistry, dietary sources, metabolism and nutritional significance. Nutr Rev 1998;56:317-33.

60. Rock KL, Kono H. The inflammatory response to cell death. Annu Rev Pathol 2008;3:99-126.

61. Hawkey CJ, Langman MJ. Non-steroidal anti inflammatory drugs: Overall risks and management. Complementary roles for COX-2 inhibitors and proton pump inhibitors. Gut 2003;52:600-8.

62. Mota ML, Thomas G, Filho JM. Anti-inflammatory actions of tannins isolated from the bark of Anacardium occidentale L. J Ethnopharmacol 1985;13:289-300.

63. Das B, Choudhury MD, Dey A, Talukdar AD, Nongalleima KH, Deb L. Antioxidant and anti-inflammatory activity of aqueous and methanol extracts of rhizome part of Drynaria quercifolia (L.) J. smith. Int J Pharm Pharm Sci 2014;6:43-9.

64. Chuang CC, McIntosh MK. Potential mechanisms by which polyphenol-rich grapes prevent obesity mediated inflammation and metabolic diseases. Annu Rev Nutr 2011;31:155-76.

65. Arun M, Satish S, Anima P. Herbal boon for wounds. Int J Pharm Pharm Sci 2013;5:1-12. 